\title{
Evaluasi Penerapan PSAK 69 'Agrikultur’ atas Aset Biologis pada Perusahaan Sawit PT X
}

\author{
Adhi Nugraha ${ }^{1}$, Aruna Wirjolukito ${ }^{2}$ \\ Magister Akuntansi, Fakultas Ekonomi dan Bisnis, Universitas Indonesia, Jakarta, Indonesia ${ }^{1}$ \\ Magister Akuntansi, Fakultas Ekonomi dan Bisnis, Universitas Indonesia, Jakarta, Indonesia ${ }^{2}$
}

\begin{abstract}
This study aims to evaluate the application of PSAK 69 to the accounting treatment of biological assets in oil palm companies in PT X in East Kalimantan. The problem in this study is that the application of PSAK 69 has changed the method of accounting treatment of biological assets from historical costs to fair value so that it can lead to different valuation methods and lack of comparability of financial statements. This research was designed using a case study method with a qualitative approach. The research instrument used was interview techniques and document review. Data analysis was performed using a descriptive qualitative analysis approach. The results showed that the accounting treatment of biological assets owned by PT X was in accordance with PSAK 69. The difference in the accounting treatment of biological assets in oil palm companies after the application of PSAK 69 was the recognition of fresh fruit bunches (FFB) agricultural products that had not been harvested. The results of the study also found that there were no specific guidelines governing the valuation of biological assets so that they could lead to different assessment methods.
\end{abstract}

Keywords. Biological Assets; Agriculture; PSAK 69.

Abstrak. Penelitian ini bertujuan untuk mengevaluasi penerapan PSAK 69 terhadap perlakuan akuntansi atas aset biologis pada perusahaan sawit di PT X di Kalimantan Timur. Permasalahan dalam penelitian ini adalah bahwa penerapan PSAK 69 ini telah mengubah metode perlakuan akuntansi atas aset biologis dari biaya historis ke nilai wajar sehingga dapat menimbulkan metode valuasi yang berbeda dan kurangnya komparabilitas laporan keuangan. Penelitian ini dirancang menggunakan metode studi kasus dengan pendekatan kualitatif. Instrumen penelitian yang digunakan dengan teknik wawancara dan penelaahan dokumen. Analisis data dilakukan dengan menggunakan pendekatan analisis kualitatif deskriptif. Hasil penelitian menunjukkan bahwa perlakuan akuntansi atas aset biologis milik PT X telah sesuai dengan PSAK 69. Perbedaan perlakuan akuntansi aset biologis pada perusahaan sawit setelah penerapan PSAK 69 adalah dengan adanya pengakuan atas produk agrikultur tandan buah segar (TBS) yang belum dipanen. Hasil penelitian juga menemukan belum adanya pedoman khusus yang mengatur penilaian aset biologis sehingga dapat mengakibatkan metode penilaian yang berbeda-beda.

Kata Kunci. aset biologis; agrikultur; psak 69.

Correspondence. adhi.nugraha72@ui.ac.id

History of article. Received: April 2019, Revision: Juli 2019, Published: September 2019

\section{PENDAhUluaN}

Agrikultur merupakan salah satu sektor yang berperan penting bagi perekonomian global. Sektor agrikultur, termasuk di dalamnya subsektor kehutanan dan perikanan, memiliki kontribusi sekitar $3.548 \%$ dari total PDB dunia (World Bank, 2019a). Di Indonesia, kontribusi sektor agrikultur selama periode 2011-2017 berada pada kisaran $13,14 \%$ - 13,51\% dari total PDB seperti terlihat pada Gambar 1.1 (World Bank, 2019b).

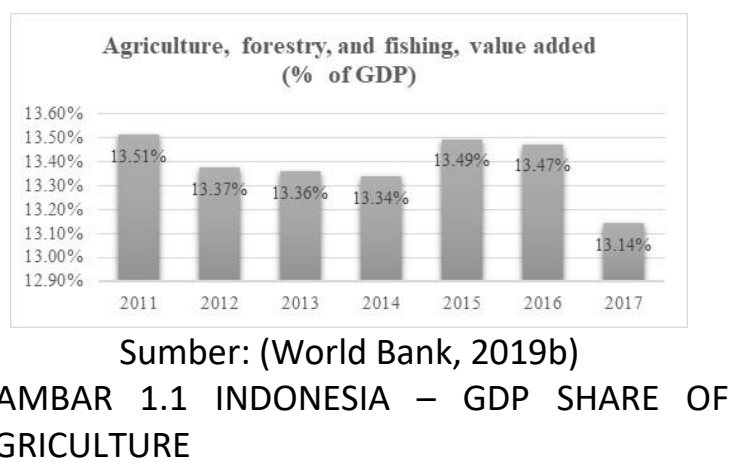


Sektor agrikultur di Indonesia dapat dibagi menjadi beberapa subsektor berdasarkan jenis lapangan usaha. Berdasarkan data pada Tabel 1.1, sektor pertanian terbagi menjadi tiga sub sektor utama yaitu: (1) Pertanian; (2) Kehutanan; dan (3) Perikanan (BPS, 2019). Dari ketiga sub sektor tersebut, pertanian masih memiliki kontribusi terbesar terhadap PDB pada tahun 2018 yaitu mencapai 9,55 persen diikuti subsektor perikanan dan kehutanan dengan kontribusi masing-masing mencapai 2,6 persen dan 0,66 persen (BPS, 2019). Sub sektor pertanian memiliki beberapa jenis lapangan usaha antara lain tanaman pangan, tanaman hortikultura, tanaman perkebunan, peternakan, dan jasa pertanian dan perburuan. Di antara jenis-jenis lapangan usaha tersebut, sektor tanaman perkebunan memiliki kontribusi terbesar yaitu mencapai 3,3 persen dari PDB diikuti oleh tanaman pangan yang memiliki kontribusi mencapai 3,03 persen dari PDB (BPS, 2019).

TABEL 1.1 DISTRIBUSI PDB ATAS DASAR TAHUN BERLAKU MENURUT LAPANGAN USAHA PADA SEKTOR PERTANIAN

\begin{tabular}{|l|c|c|c|}
\hline Jenis Lapangan Usaha & $\mathbf{2 0 1 6}$ & $\mathbf{2 0 1 7}$ & $\mathbf{2 0 1 8}$ \\
\hline Pertanian, Kehutanan, dan Perkebunan & $13,47 \%$ & $13,14 \%$ & $12,81 \%$ \\
\hline 1. Pertanian & $10,27 \%$ & $9,90 \%$ & $9,55 \%$ \\
\hline a. Tanaman Pangan & $3,43 \%$ & $3,22 \%$ & $3,03 \%$ \\
\hline b. Tanaman Hortikultura & $1,51 \%$ & $1,44 \%$ & $1,47 \%$ \\
\hline c. Tanaman Perkebunan & $3,46 \%$ & $3,47 \%$ & $3,30 \%$ \\
\hline d. Peternakan & $1,62 \%$ & $1,57 \%$ & $1,56 \%$ \\
\hline e. Jasa Pertanian dan Perburuan & $0,20 \%$ & $0,19 \%$ & $0,19 \%$ \\
\hline 2. Kehutanan dan Penebangan Kayu & $0,70 \%$ & $0,67 \%$ & $0,66 \%$ \\
\hline 3. Perikanan & $2,56 \%$ & $2,57 \%$ & $2,60 \%$ \\
\hline
\end{tabular}

Sumber: (BPS, 2019)

Meskipun sektor agrikultur memiliki kontribusi yang penting bagi perekonomian Indonesia, namun akuntansi terkait sektor agrikultur baru menjadi perhatian pembuat standar di Indonesia tepatnya pada tahun 2015 dengan diterbitkannya Pernyataan Standar Akuntansi Keuangan (PSAK) Nomor 69 tentang Agrikultur oleh Dewan Standar Akuntansi Keuangan Ikatan Akuntan Indonesia (DSAK-IAI). PSAK 69 merupakan adopsi dari International Accounting Standard (IAS) 41 yang merupakan standar akuntansi internasional untuk agrikultur. Dengan adanya PSAK 69 ini, maka perusahaan agrikultur diharuskan menerapkan standar ini untuk laporan keuangan yang dimulai pada atau setelah 1 Januari 2018. PSAK 69 ini diharapkan dapat membantu perusahaan agrikultur untuk menghasilkan informasi yang lebih berkualitas yang dapat membantu pengguna dalam mengambil keputusan secara lebih tepat dan juga dapat meningkatkan akuntabilitas perusahaan.

Agrikultur memiliki karakteristik yang berbeda dengan sektor lainnya yaitu dengan adanya aset biologis. Keunikan karakteristik pada aset biologis terjadi karena aset biologis dapat mengalami proses transformasi yang nilainya akan berubah dari waktu ke waktu sehingga kurang relevan apabila diukur menggunakan biaya historis (Baroroh, Yanto, Fajarrini, \& Agustina, 2018). Karena karakteristik yang unik ini, perusahaan yang bergerak di bidang agrikultur cenderung menyampaikan informasi yang lebih bias daripada perusahaan yang bergerak di bidang lainnya, terutama dalam hal pengakuan, pengukuran, presentasi, dan pengungkapan aset biologis (Farida, 2013). Berdasarkan latar belakang tersebut, peneliti tertarik untuk meneliti terkait evaluasi penerapan PSAK 69 ini terhadap aset biologis, terutama pada perusahaan yang bergerak dalam bidang perkebunan sawit.

Masalah penelitian yang diangkat dalam penelitian ini adalah bahwa penerapan PSAK 69 yang merupakan adopsi IAS 41 ini telah mengubah metode perlakuan akuntansi atas aset biologis dari biaya historis ke nilai wajar. Hal ini menjadi masalah karena perubahan ini akan menimbulkan metode valuasi yang bervariasi dan juga mengakibatkan penurunan kualitas dalam hal komparabilitas laporan keuangan (Elad \& Herbohn, 2019). Lebih lanjut, pengukuran berbasis nilai wajar dianggap relatif lebih sulit dan mahal ketimbang pengukuran berbasis biaya historis. Hal ini didukung oleh studi yang dilakukan oleh Benston yang menemukan bahwa valuasi nilai wajar aset non keuangan sangat sulit untuk diterapkan dan dapat dengan mudah dimanipulasi (Benston, 2008). Selain itu, valuasi nilai wajar kemungkinan akan mahal bagi investor dan akuntan publik independen (Benston, 2008). Namun demikian, penggunaan nilai wajar memiliki suatu kelebihan yaitu dapat meningkatkan kualitas relevansi suatu informasi keuangan dibanding biaya historis. 
Penelitian ini bertujuan untuk memahami dan mengevaluasi penerapan PSAK No. 69 tentang Agrikultur atas aset biologis di PT $X$ sehingga diharapkan dapat memberikan solusi implementasi yang sesuai bagi perusahaan. Penelitian ini memiliki keterbatasan ruang lingkup pada perusahaan perkebunan sawit di Indonesia. Peneliti memilih perusahaan sawit sebagai subjek studi karena belum banyak penelitian yang membahas subjek ini terutama yang berkaitan dengan penerapan PSAK 69. Penelitian ini terbatas pada perlakuan penerapan PSAK 69 di PT $X$ terutama terkait perlakuan atas aset biologis. Peneliti memilih studi di PT $X$ karena pada PT $X$ inilah semua pertanyaanpertanyaan penelitian dapat terjawab.

Penelitian ini diharapkan dapat bermanfaat dalam memberi evaluasi terkait penerapan PSAK 69 pada aset biologis di PT X. Selain itu, penelitian ini diharapkan juga dapat menambah manfaat bagi keilmuan di bidang akuntansi keuangan serta dapat menjadi bahan literatur untuk penelitian selanjutnya

Penelitian ini menggunakan metodologi studi kasus eksplorasi dengan pendekatan kualitatif. Pengumpulan data dilakukan baik menggunakan data primer maupun data sekunder. Instrumen penelitian yang digunakan dalam penelitian ini berupa dokumentasi dan wawancara. Analisis penelitian dan data dilakukan dengan pendekatan analisis kualitatif deskriptif.

\section{KERANGKA PENELITIAN \& HIPOTESIS}

Pada penelitian ini, dilakukan tinjauan kepustakaan terhadap studi-studi terdahulu yang relevan dengan permasalahan penelitian. Tujuan dari studi terdahulu ini adalah untuk menganalisis secara kritis celah penelitian (research gap) yang ada sehingga penelitian ini diharapkan akan memberikan kontribusi yang optimal.

Dalam studi Herbohn \& Herbohn (2006), ditemukan bahwa penerapan IAS telah dikritik karena memperkenalkan metode pengukuran yang tidak sesuai untuk aset biologis. Kepatuhan terhadap IAS 41 akan memungkinkan penyusun laporan keuangan untuk memilih metode dalam menentukan nilai wajar aset biologis (Herbohn \& Herbohn, 2006). Selain itu, adanya pengakuan atas keuntungan dan kerugian akibat perubahan nilai wajar aset biologis dan hasil panen secara nyata akan mempengaruhi laporan laba rugi, yang berdampak pada volatilitas yang lebih besar ke dalam pendapatan yang dilaporkan (Herbohn \& Herbohn, 2006).

Dalam studi Martani et al. (2017), ditemukan bahwa penerapan IFRS memungkinkan terjadinya biaya yang lebih tinggi dalam penyusunan laporan keuangan untuk mendapatkan nilai wajar aset biologis. Penilaian aset biologis mungkin dapat menjadi bias karena adanya perbedaan dalam pendekatan atau asumsi yang digunakan dalam proses penilaian (Martani et al., 2017). Menurut Martani et al. (2017), pedoman akuntansi untuk industri tertentu masih diperlukan untuk memberikan panduan tentang bagaimana entitas menyajikan, mengukur, dan mengungkapkan aset dan pendapatan yang terkait dengan aset biologis dan produk agrikultur. Pedoman akuntansi diharapkan dapat memberikan aturan yang lebih rinci tentang bagaimana penilaian dilakukan untuk menghindari bias dalam proses penilaian tetapi tetap dipastikan sesuai dengan standar (Martani et al., 2017).

Dalam studi Elad \& Herbohn (2019), ditemukan bahwa entitas agrikultur di negara UK, Perancis, dan Australia menerapkan IAS 41 menggunakan metode valuasi dan pengungkapan yang berbeda-beda. Beberapa responden dalam studi tersebut juga menyatakan bahwa biaya yang timbul akibat pengukuran dan pelaporan aset biologis dengan menggunakan nilai wajar melebihi manfaat yang didapatkan (Elad \& Herbohn, 2019).

Dalam studi Lefter \& Roman (2007), ditemukan bahwa pengakuan perubahan nilai wajar aset biologis pada laporan laba rugi yang diakibatkan oleh proses transformasi akan menyediakan informasi yang lebih relevan dalam pengambilan keputusan. Namun demikian, di sisi lain, pengakuan perubahan nilai wajar tersebut juga akan membawa pada volatilitas dan risiko yang lebih tinggi bagi pengguna laporan keuangan (Lefter \& Roman, 2007).

Berbeda dengan penelitian Herbohn \& Herbohn (2006), Lefter \& Roman (2007) yang menemukan bahwa IAS 41 dapat mempengaruhi volatilitas pendapatan dalam laporan laba rugi, 
penelitian yang dilakukan oleh Maruli \& Mita (2010) justru memperlihatkan hasil yang berbeda. Dalam studinya, Maruli \& Mita (2010) menemukan bahwa tidak ada pengaruh yang signifikan dari penerapan pendekatan nilai wajar terhadap volatilitas pendapatan perusahaan.

Berdasarkan studi terdahulu terkait penerapan IAS pada aset biologis, peneliti menyimpulkan bahwa penerapan perlakuan nilai wajar pada aset biologis telah menimbulkan perdebatan di kalangan peneliti. Pihak-pihak yang mendukung penerapan nilai wajar pada aset biologis berargumen bahwa penggunaan nilai wajar dianggap dapat memberikan informasi yang lebih relevan bagi pengguna keuangan karena aset yang dicatat lebih mencerminkan kondisi realitas. Sedangkan pihak-pihak yang menentang penerapan nilai wajar pada aset biologis berargumen bahwa penggunaan nilai wajar dapat memungkinkan bias dan juga volatilitas yang lebih tinggi dalam laporan keuangan.

PSAK 69 adalah standar yang mengatur perlakuan akuntansi yang terkait dengan aktivitas agrikultur. PSAK 69 mendefinisikan aktivitas agrikultur sebagai "manajemen transformasi biologis dan panen aset biologis oleh entitas untuk dijual atau untuk dikonversi menjadi produk agrikultur atau menjadi aset biologis tambahan" (IAI, 2016, par 5). Dalam PSAK 69, yang dimaksud dengan aset biologis adalah hewan dan tanaman hidup (IAI, 2016). Transformasi biologis terdiri dari proses pertumbuhan, degenerasi, produksi, dan prokreasi yang dapat mengakibatkan perubahan aset biologis baik secara kualitas maupun kuantitas (IAI, 2016).

Sama seperti perlakuan pada aset lainnya, aset biologis dan produk agrikultur diakui ketika, dan hanya ketika (1) entitas memiliki kendali atas aset biologis, (2) manfaat ekonomis terkait aset tersebut kemungkinan besar mengalir ke entitas, dan (3) nilai aset biologis tersebut dapat diukur dengan andal (IAI, 2016).

Meskipun aset biologis meliputi hewan dan tanaman hidup (IAI, 2016), namun terdapat pengecualian perlakuan akuntansi untuk tanaman hidup yang memenuhi definisi tanaman produktif. Dalam PSAK 69, tanaman produktif termasuk dalam ruang lingkup PSAK 16 'Aset Tetap', bukan PSAK 69. Dalam perlakuannya, tanaman produktif diibaratkan seperti mesin karena memiliki kemampuan dalam menghasilkan produk agrikultur. Oleh karena itu, perlakuan akuntansi tanaman produktif ini sama seperti aset tetap di mana perusahaan dapat memilih untuk menggunakan metode biaya atau revaluasi.

PSAK 69 mengatur bahwa suatu aset biologis termasuk dalam definisi tanaman produktif apabila memenuhi kriteria sebagai berikut: (1) digunakan untuk menghasilkan produk agrikultur; (2) diharapkan dapat menghasilkan produk untuk jangka waktu lebih dari satu periode; dan (3) kemungkinan kecil dijual sebagai produk agrikultur, kecuali untuk penjualan sisa insidental.

Pengukuran aset biologis milik entitas dilakukan pada saat pengakuan awal dan setiap akhir periode pelaporan keuangan pada nilai wajar dikurangi biaya untuk menjual, sedangkan produk agrikultur yang dipanen diukur pada nilai wajar dikurangi biaya untuk menjual pada titik panen (IAI, 2016). Keuntungan dan kerugian yang timbul ketika pengakuan awal dan dari perubahan nilai wajar aset biologis dan produk agrikultur dimasukkan dalam laporan laba rugi pada saat periode terjadinya (IAI, 2016). Nilai wajar didefinisikan sebagai "harga yang akan diterima untuk menjual suatu aset atau harga yang dibayar untuk mengalihkan suatu liabilitas dalam transaksi teratur antara pelaku pasar pada tanggal pelaporan" (IAI, 2016, par 08).

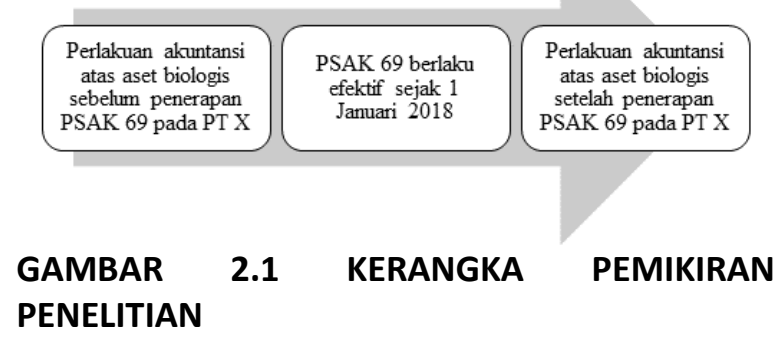

\section{METODE PENELITIAN}

Penelitian ini dirancang menggunakan metode studi kasus. Penelitian studi kasus didefinisikan sebagai pencarian pengetahuan secara empiris yang digunakan untuk menyelidiki 
suatu fenomena secara mendalam dan dalam konteks kehidupan nyata, terutama ketika batasan antara fenomena dan konteks tersebut masih belum dapat dibuktikan dengan jelas (Yin, 2009). Peneliti menggunakan metode studi kasus karena pertanyaan penelitian yang dirumuskan berfokus pada bagaimana atau mengapa suatu fenomena terjadi sehingga akan lebih tepat dan relevan jika diteliti menggunakan metode studi kasus. Selain itu, studi kasus memungkinkan peneliti untuk menggali informasi lebih dalam sehingga dapat menjawab pertanyaan penelitian dengan lebih tepat.

Penelitian ini dirancang menggunakan pendekatan kualitatif. Penelitian kualitatif adalah pendekatan holistik yang melibatkan penemuan (Creswell, 1994). Penelitian kualitatif juga digambarkan sebagai model yang berlangsung ataupun yang terjadi dimana memungkinkan peneliti untuk mengembangkan tingkat detil dari keterlibatan yang tinggi dalam pengalaman yang sebenarnya (Creswell, 1994). Peneliti menggunakan pendekatan kualitatif karena dapat menggambarkan fenomena yang terjadi secara lebih detil dan menyeluruh. Selain itu, pendekatan kualitatif digunakan karena data dalam penelitian ini merupakan data berbasis teks (text-based data) sehingga lebih tepat dan relevan apabila dilakukan dengan pendekatan kualitatif.

Proses pengumpulan data diawali dengan rekrutmen unit analisis yang menjadi subjek penelitian yaitu salah satu perusahaan kelapa sawit yang berada di Kalimantan Timur yaitu PT $X$. Untuk itu, peneliti kemudian membuat surat permohonan penelitian yang ditujukan kepada PT $X$. Proses pengumpulan data, peneliti menjunjung tinggi kode etik penelitian dan integritas data. Setiap data yang diperoleh dari unit analisis akan dijamin validitas dan kerahasiaannya.

Penelitian ini menggunakan jenis data kualitatif dam kuantitatif. Data kualitatif adalah data yang bersifat verbal dan bukan berupa angka, sedangkan data kuantitatif adalah data yang berupa angka. Sumber data diambil dari data primer dan sekunder. Data primer adalah data yang diperoleh peneliti secara langsung dari sumber datanya sedangkan data sekunder adalah data yang diperoleh peneliti dari sumber yang sudah ada. Data primer yang digunakan antara lain dokumen internal perusahaan dan hasil wawancara. Untuk data sekunder, penulis menggunakan beberapa dokumentasi seperti laporan keuangan perusahaan lain sebagai pembanding.

Menurut Birmingham dan Wilkinson dalam Shauki (2018), instrumen penelitian dibagi menjadi 6 kategori yaitu 1) kuesioner, 2) wawancara, 3) analisis konten, 4) fokus grup, 5) observasi, dan 6) meneliti sesuatu yang dikatakan dan dilakukan seseorang. Pada penelitian ini, instrumen penelitian yang digunakan adalah analisis dokumentasi dan wawancara.

Pada penelitian ini, analisis data dilakukan dengan menggunakan teknik analisis deskriptif kualitatif. Menurut Neuman (2014), analisis deskriptif adalah metode yang digunakan untuk menjelaskan permasalahan yang terjadi secara lebih spesifik. Tujuan dari analisis deskriptif adalah untuk memberikan suatu gambaran dari data yang diperoleh sehingga dapat memberikan informasi mengenai masalah yang terjadi (Neuman, 2014).

Unit analisis dalam penelitian ini adalah single unit analysis. Subjek penelitian dalam penelitian ini adalah PT $X$, salah satu perusahaan sawit di Indonesia. PT $X$ adalah perusahaan yang bergerak di bidang perkebunan kelapa sawit, penjualan tandan buah segar (TBS), pengolahan minyak sawit mentah (crude palm oil/CPO) dan minyak inti sawit (palm kernel oil). Dalam anggaran dasarnya, PT X memiliki ruang lingkup kegiatan perkebunan, agro-industri, termasuk namun tidak terbatas pada budidaya dan pengolahan pasca panen, pembibitan, industri pertanian tanaman pangan, tanaman perkebunan dan hortikultura, dan agrobisnis.

Dalam menjalankan operasinya, PT $X$ memiliki areal perkebunan yang berlokasi di Kabupaten Kutai Kartanegara, Provinsi Kalimantan Timur dengan kepemilikan hak guna usaha (HGU) atas lahan seluas 8.600 hektar. PT X memulai operasi secara komersial sejak tahun 2011 dan memiliki kantor pusat yang berada di Jalan Sudirman, Jakarta Selatan. PT X merupakan entitas anak dari PT Y Tbk dan termasuk dalam suatu kelompok usaha yang dikendalikan oleh Z 
Holding Pte Ltd sejak 25 Januari 2017 setelah mengakuisisi $61,79 \%$ saham PT Y Tbk.

\section{HASIL DAN PEMBAHASAN}

Pada bagian ini, peneliti akan membahas mengenai hasil temuan dari penelaahan dokumentasi dari beberapa sumber data. Dokumentasi yang ditelaah meliputi kertas kerja laporan keuangan dan juga dokumentasi terkait kertas kerja penilaian aset biologis pada PT X. Selain itu, peneliti juga mengambil beberapa data eksternal laporan keuangan perusahaan sawit publik sebagai perbandingan.

TABEL 4.1 PROFIL TANAMAN SAWIT PADA PT $X$

\begin{tabular}{|c|c|r|r|r|r|r|}
\hline $\begin{array}{c}\text { Tahun } \\
\text { Tanam }\end{array}$ & $\begin{array}{c}\text { Tanaman } \\
\text { Menghasilkan } \\
\text { di Tahun }\end{array}$ & $\begin{array}{c}\text { Biaya } \\
\text { Perolehan } \\
\text { (Rupiah) }\end{array}$ & $\begin{array}{c}\text { Persentase } \\
\text { Biaya (\%) }\end{array}$ & $\begin{array}{c}\text { Luas } \\
\text { Areal } \\
\text { Tanam } \\
\text { (dalam } \\
\text { hektar) }\end{array}$ & $\begin{array}{c}\text { Jumlah } \\
\text { Pokok } \\
\text { tanaman }\end{array}$ & $\begin{array}{c}\text { Persentase } \\
\text { Pokok } \\
\text { Tanaman } \\
\text { (\%) }\end{array}$ \\
\hline 2008 & 2011 & 54.870 .671 .157 & $39,9 \%$ & 1.129 & 147.455 & $53,5 \%$ \\
\hline 2009 & 2012 & 36.649 .812 .118 & $26,6 \%$ & 897 & 77.665 & $28,2 \%$ \\
\hline 2010 & 2013 & 45.176 .240 .864 & $32,8 \%$ & 711 & 50.215 & $18,2 \%$ \\
\hline 2011 & 2014 & 835.342 .830 & $0,6 \%$ & 2 & 33 & $0,0 \%$ \\
\hline Total & & $\mathbf{1 3 7 . 5 3 2 . 0 8 6 . 9 6 9}$ & $\mathbf{1 0 0 \%}$ & $\mathbf{2 . 7 3 8}$ & $\mathbf{2 7 5 . 3 6 8}$ & $\mathbf{1 0 0 \%}$ \\
\hline
\end{tabular}

Sumber: PT X (2019)

Tabel 4.1 menunjukkan informasi mengenai profil tanaman kelapa sawit yang dimiliki oleh PT $X$. Dari tabel tersebut, kita dapat melihat bahwa periode penanaman kelapa sawit di PT $X$ dilakukan antara tahun 2008 hingga 2011 dengan total biaya perolehan atau nilai investasi mencapai Rp137.532.086.969. Dengan asumsi bahwa tanaman sawit akan mulai menghasilkan tandan buah segar (TBS) pada tahun ke tiga sejak penanaman, maka seluruh tanaman sawit yang dimiliki oleh PT $X$ telah menjadi tanaman menghasilkan antara tahun 2011 hingga 2014. Total areal lahan yang ditanami kelapa sawit mencapai 2.738 hektar dengan jumlah pokok tertanam mencapai 275.368 pokok tanaman.

Biaya perolehan yang dicatat merupakan akumulasi biaya yang dikeluarkan selama periode tanaman belum menghasilkan yang meliputi biaya terkait pengembangan tanaman seperti biaya persiapan dan pembukaan lahan, biaya pemupukan, biaya pemeliharaan, dan juga biaya tidak langsung lainnya yang dialokasikan berdasarkan luas lahan tertanam. Pada saat tanaman mulai menghasilkan, akumulasi harga perolehan tersebut kemudian direklasifikasi ke tanaman menghasilkan dan diamortisasi berdasarkan umur ekonomisnya. Pada PT X, tanaman menghasilkan diamortisasi selama estimasi umur produktif yaitu selama 20 tahun menggunakan metode garis lurus. Biaya amortisasi yang dibebankan setiap periode akan masuk ke dalam klasifikasi beban pokok penjualan perusahaan.

\section{TABEL 4.2 KLASIFIKASI ASET BIOLOGIS PADA PT} $X$ SEBELUM PENERAPAN PSAK 69

\begin{tabular}{|l|c|c|}
\hline Jenis aset biologis & $\mathbf{2 0 1 8}$ & $\mathbf{2 0 1 7}$ \\
\hline Tanaman perkebunan & & \\
\hline - Tanaman menghasilkan (neto) & 95.943 .537 .073 & 102.820 .141 .422 \\
\hline - Tanaman belum menghasilkan (neto) & - & - \\
\hline $\begin{array}{l}\text { Nilai aset biologis sebelum penerapan } \\
\text { PSAK 69 }\end{array}$ & $\mathbf{9 5 . 9 4 3 . 5 3 7 . 0 7 3}$ & $\mathbf{1 0 2 . 8 2 0 . 1 4 1 . 4 2 2}$ \\
\hline
\end{tabular}

Sumber: PT X (2019) telah diolah

TABEL 4.3 KLASIFIKASI ASET BIOLOGIS PADA PT $X$ SETELAH PENERAPAN PSAK 69

\begin{tabular}{|l|c|c|}
\hline Jenis aset biologis & $\mathbf{2 0 1 8}$ & $\mathbf{2 0 1 7}$ \\
\hline Produk agrikultur bertumbuh & 676.693 .221 & 333.369 .338 \\
\hline Tanaman perkebunan & & \\
\hline - Tanaman menghasilkan (neto) & 95.943 .537 .073 & 102.820 .141 .422 \\
\hline - Tanaman belum menghasilkan (neto) & - & - \\
\hline $\begin{array}{l}\text { Nilai aset biologis setelah penerapan } \\
\text { PSAK 69 }\end{array}$ & $\mathbf{9 6 . 6 2 0 . 2 2 6 . 9 9 7}$ & $\mathbf{1 0 3 . 1 5 3 . 5 1 0 . 7 6 0}$ \\
\hline
\end{tabular}

Sumber: PT X (2019) telah diolah

Tabel 4.2 dan 4.3 menunjukkan perbandingan klasifikasi aset biologis sebelum dan setelah penerapan PSAK 69. Dari tabel tersebut, dapat disimpulkan bahwa penerapan PSAK 69 telah membawa perubahan pada perlakuan akuntansi aset biologis pada PT X yaitu dengan ada pencatatan terkait produk agrikultur bertumbuh yang diukur pada nilai wajar. Produk agrikultur bertumbuh yang dicatat ini merupakan estimasi nilai wajar TBS yang masih berada di pohon.

Sebelum penerapan PSAK 69, PT X hanya mencatat aset biologis berupa tanaman perkebunan di mana dibagi menjadi dua jenis yaitu tanaman belum menghasilkan (TBM) dan tanaman menghasilkan (TM). TBM adalah tanaman kelapa sawit yang berada pada tahap pemeliharaan awal di mana belum dapat dipanen secara komersial. Pada umumnya, periode TBM berlangsung antara nol sampai dengan tiga tahun sejak penanaman tergantung pada kualitas bibit dan kondisi lahan. TM adalah tanaman yang telah melewati periode pemeliharaan awal dan sudah dapat dipanen sesuai dengan siklus hidupnya. Pada umumnya, tanaman kelapa sawit mulai memasuki periode produktif setelah berumur tiga tahun.

Setelah penerapan PSAK 69, klasifikasi aset biologis yang dicatat pada laporan keuangan PT X 
mengalami perubahan dengan adanya pencatatan produk agrikultur bertumbuh berupa TBS yang belum dipanen. TBS merupakan produk agrikultur karena dihasilkan dari tanaman sawit yang dimiliki perusahaan. Pencatatan ini telah sesuai dengan aturan dalam PSAK 69 paragraf 05C yang menyatakan bahwa produk yang tumbuh atau dihasilkan dari tanaman produktif merupakan aset biologis sehingga harus diakui dalam laporan keuangan (IAI, 2016). Dampak dari pencatatan atas produk agrikultur bertumbuh ini adalah aset biologis PT $\mathrm{X}$ mengalami kenaikan sebesar Rp676.693.221 pada tahun 2018 dan sebesar Rp333.369.338 pada tahun 2017. Pada PT $X$, produk agrikultur berupa TBS yang belum dipanen ini dicatat pada nilai wajar dikurangi biaya untuk menjual.

Menurut peneliti, pencatatan produk agrikultur berupa TBS pada nilai wajar ini pada dasarnya akan meningkatkan kualitas relevansi suatu laporan keuangan. Hal ini karena pertumbuhan TBS pada tanaman produktif secara substansi telah meningkatkan nilai ekonomi perusahaan sehingga sudah seharusnya tercermin dalam laporan keuangan. Akan tetapi, belum adanya standar yang mengatur secara teknis pengukuran nilai wajar suatu aset biologis juga dapat menimbulkan teknik pengukuran yang berbeda-beda untuk setiap perusahaan sehingga akan menurunkan kualitas komparabilitas suatu laporan keuangan.

Sebagai analisis tambahan, peneliti mengambil data aset produk agrikultur bertumbuh dan tanaman menghasilkan dari dua perusahaan sawit terbuka yang besar di Indonesia yaitu PT Astra Agro Lestari Tbk,(AALI) dan PT Sawit Sumbermas Sarana Tbk. (SSMS) dari laporan keuangan periode 2018 yang telah diaudit. Berikut adalah hasil perbandingan nilai aset biologis pada PT X, AALI, dan SSMS untuk periode 31 Desember 2018 dan 2017 (dalam jutaan rupiah).

TABEL 4.4 PERBANDINGAN NILAI ASET BIOLOGIS PADA PT X, AALI, DAN SSMS (DALAM JUTAAN RUPIAH)

\begin{tabular}{|l|r|r|r|r|r|r|}
\hline & \multicolumn{3}{|c|}{ 31 Desember 2018 } & \multicolumn{3}{|c|}{ 31 Desember 2017 } \\
\cline { 2 - 7 } & PT X & \multicolumn{1}{|c|}{ SSMS } & \multicolumn{1}{c|}{ AALI } & \multicolumn{1}{c|}{ PT X } & \multicolumn{1}{c|}{ SSMS } & \multicolumn{1}{c|}{ AALI } \\
\hline $\begin{array}{l}\text { Produk agrikultur } \\
\text { bertumbuh }\end{array}$ & 677 & 79.366 & 89.136 & 333 & 171.928 & 234.718 \\
\hline $\begin{array}{l}\text { Tanamann menghasilkan } \\
\text { (neto) }\end{array}$ & 95.944 & 2.132 .419 & 5.681 .689 & 102.820 & 2.178 .633 & 5.154 .777 \\
\hline $\begin{array}{l}\text { Persentase nilai produk } \\
\text { agrikultur bertumbuh } \\
\text { terhadap nilai aset } \\
\text { tanaman menghasilkan }\end{array}$ & $0,71 \%$ & $3,72 \%$ & $1,57 \%$ & $0,32 \%$ & $7,89 \%$ & $4,55 \%$ \\
\hline
\end{tabular}

Sumber: PT X, AALI, SSMS (2019), telah diolah kembali

Berdasarkan Tabel 4.4, kita dapat melihat bahwa ketiga perusahaan mencatat nilai aset biologis dari produk agrikultur bertumbuh berupa TBS. Dari Tabel 4.4 tersebut, dapat dilihat bahwa pencatatan aset biologis berupa TBS pada ketiga perusahaan ini sangat bervariasi untuk setiap periode. Sebagai contoh, nilai produk agrikultur bertumbuh yang dicatat pada AALI dan SSMS pada periode 2018 lebih rendah dibandingkan pada periode 2017. Sebaliknya, pada PT X, nilai produk agrikultur bertumbuh (TBS) yang dicatat pada periode 2018 justru lebih tinggi dibandingkan dengan periode 2017. Beberapa faktor yang dapat mempengaruhi nilai aset biologis yang dicatat antara lain jangka waktu pemanenan, harga pasar TBS, dan estimasi kuantitas TBS. Perubahan nilai aset biologis yang fluktuatif secara langsung akan mempengaruhi fluktuasi laba rugi perusahaan karena keuntungan atau kerugian akibat perubahan aset biologis harus diakui dalam laporan laba rugi pada saat periode terjadinya. Hasil temuan ini selaras dengan penelitian dan (Lefter \& Roman, 2007) yang menemukan perlakuan akuntansi aset biologis menggunakan nilai wajar dapat mempengaruhi volatilitas pendapatan dalam laporan laba rugi.

\section{Metode Pengukuran Nilai Wajar TBS pada PTX}

Seperti yang telah dijelaskan sebelumnya, salah satu perbedaan utama penerapan PSAK 69 atas aset biologis perusahaan sawit adalah dengan adanya pengakuan atas nilai produk agrikultur TBS yang masih berada di pohon. Saat ini, belum ada pedoman khusus yang mengatur secara rinci terkait bagaimana perusahaan harus mengukur nilai aset biologisnya, namun PSAK 68 memberikan panduan umum bagi perusahaan dalam mengukur nilai wajar aset atau liabilitasnya. Tabel 4.5 memperlihatkan teknik pengukuran yang digunakan oleh PT $X$ untuk mengestimasi nilai wajar TBS yang belum dipanen dari pohonnya.

TABEL 4.5 PENGUKURAN NILAI WAJAR PRODUK AGRIKULTUR BERTUMBUH TANDAN BUAH SEGAR PADA PT $X$ 


\begin{tabular}{|l|l|r|r|}
\hline & & $\mathbf{2 0 1 8}$ & $\mathbf{2 0 1 7}$ \\
\hline A & $\begin{array}{l}\text { Estimasi kuantitas TBS dalam kg } \\
\text { (menggunakan basis realisasi TBS yang } \\
\text { dipanen dalam satu bulan ke depan) }\end{array}$ & 1.300 .130 & 506.117 \\
\hline B & Asumsi harga TBS (Rp/kg) & $1.071,3$ & $1.739,0$ \\
\hline C & Estimasi nilai wajar TBS (A X B) & 1.392 .829 .269 & 880.137 .463 \\
\hline D & Biava Panen selama periode 1 bulan ke depan & 716.136 .048 & 546.768 .125 \\
\hline & & & \\
\hline E & Nilai aset biologis TBS (C - D) & 676.693 .221 & 333.369 .338 \\
\hline
\end{tabular}

Sumber: PT X (2019) telah diolah

Berdasarkan Tabel 4.5, kita dapat melihat bahwa pengukuran nilai aset TBS pada PT $X$ menggunakan pendekatan pendapatan yaitu dengan cara menghitung estimasi nilai wajar TBS dikurangi dengan biaya panen. Estimasi nilai wajar TBS diperoleh dengan cara menghitung estimasi kuantitas TBS dengan asumsi harga TBS. Pada PT X, acuan harga TBS yang digunakan adalah harga TBS yang ditetapkan oleh Gubernur setempat yang dibantu oleh tim penetapan harga Dinas Perkebunan (Disbun) Provinsi Kalimantan Timur. Berdasarkan acuan harga TBS Disbun, PT X kemudian menghitung rata-rata yang disesuaikan dengan umur tanaman. Tabel 4.6 dan 4.7 memperlihatkan teknik yang digunakan oleh PT X untuk menghitung asumsi harga pasar TBS untuk periode 2018 dan 2017.

TABEL 4.6 PERHITUNGAN ASUMSI HARGA PASAR TBS PERIODE DESEMBER 2018

\begin{tabular}{|c|c|c|c|c|}
\hline $\begin{array}{r}\text { Umur } \\
\text { tanaman per } \\
31 \text { Desember } \\
2018\end{array}$ & $\begin{array}{r}\text { Harga TBS } \\
\text { Disbun } \\
\text { berdasarkan } \\
\text { umur } \\
\text { tanaman } \\
(\mathrm{Rp} / \mathrm{kg})\end{array}$ & $\begin{array}{r}\text { Jumlah } \\
\text { pokok } \\
\text { tanaman }\end{array}$ & $\begin{array}{r}\text { Persentase } \\
\text { jumlah } \\
\text { pokok } \\
\text { tertanam }\end{array}$ & $\begin{array}{r}\text { Rata-rata tertimbang } \\
\text { Harga TBS per } \\
\text { 31 Desember } 2018\end{array}$ \\
\hline 10 & $1.081,05$ & 147.455 & $53,5 \%$ & \multirow{4}{*}{$\begin{array}{c}(1.081,05 \times 53,5 \%)+ \\
(1.068,44 \times 28,2 \%)+ \\
(1.047,10 \times 18,2 \%)+ \\
(1.039,19 \times 0,0 \%)=\end{array}$} \\
\hline 9 & $1.068,44$ & 77.655 & $28,2 \%$ & \\
\hline 8 & $1.047,10$ & 50.215 & $18,2 \%$ & \\
\hline 7 & $1.039,19$ & 33 & $0,0 \%$ & \\
\hline & & 275.368 & $100 \%$ & $\mathrm{Rp}_{\mathrm{p}} 1.071 .3 / \mathrm{kg}$ \\
\hline
\end{tabular}

Sumber: PT X (2019) telah diolah

TABEL 4.7 PERHITUNGAN ASUMSI HARGA PASAR TBS PERIODE DESEMBER 2017

\begin{tabular}{|c|c|c|c|c|}
\hline $\begin{array}{r}\text { Umur } \\
\text { tanaman per } \\
31 \text { Desember } \\
2017\end{array}$ & $\begin{array}{r}\text { Harga TBS } \\
\text { Disbun } \\
\text { berdasarkan } \\
\text { umur } \\
\text { tanaman } \\
(\mathrm{Rp} / \mathrm{kg})\end{array}$ & $\begin{array}{r}\text { Jumlah } \\
\text { pokok } \\
\text { tanaman }\end{array}$ & $\begin{array}{r}\text { Persentase } \\
\text { jumlah } \\
\text { pokok } \\
\text { tertanam }\end{array}$ & $\begin{array}{r}\text { Rata-rata tertimbang } \\
\text { Harga TBS per } \\
\text { 31 Desember 2017 }\end{array}$ \\
\hline 9 & $1.758,4$ & 147.455 & $53,5 \%$ & \multirow{4}{*}{$\begin{array}{r}(1.758,4 \times 53,5 \%)+ \\
(1.722,6 \times 28,2 \%)+ \\
(1.709,9 \times 18,2 \%)+ \\
(1.698,5 \times 0,0 \%)=\end{array}$} \\
\hline 8 & $1.722,6$ & 77.655 & $28,2 \%$ & \\
\hline 7 & $1.709,9$ & 50.215 & $18,2 \%$ & \\
\hline 6 & $1.698,5$ & 33 & $0,0 \%$ & \\
\hline & & 275.368 & $100 \%$ & $\mathrm{Rp} 1.739 / \mathrm{kg}$ \\
\hline
\end{tabular}

Sumber: PT X (2019) telah diolah

Selain menentukan asumsi harga pasar TBS, PT $X$ juga menentukan estimasi kuantitas TBS yang masih ada di pohon pada saat tanggal pelaporan. Dalam menentukan estimasi kuantitas TBS yang belum terpanen, PT $X$ menggunakan asumsi yang didasarkan pada realisasi panen setelah tanggal pelaporan. Berdasarkan Tabel 4.5, kita dapat melihat bahwa PT $X$ menggunakan basis realisasi TBS yang dipanen selama satu bulan setelah tanggal pelaporan. Estimasi tersebut didasarkan pada pengalaman sebelumnya di mana diperkirakan buah kelapa sawit yang masih terdapat di pohon akan terealisasi dalam waktu satu bulan ke depan.

Berdasarkan hasil wawancara, peneliti menemukan bahwa penerapan PSAK 69 ini memiliki dampak terhadap perlakuan akuntansi atas aset biologis di PT $X$ dalam hal pencatatan aset biologis TBS. Selain itu, peneliti juga menemukan bahwa khusus untuk tanaman produktif, perlakuan akuntansinya tetap menggunakan PSAK 16 yang diperlakukan sama seperti aset tetap di mana perusahaan dapat memilih untuk menggunakan metode biaya atau revaluasi. Hal tersebut didukung oleh kutipan wawancara terhadap responden berikut ini.

"Kalau menurut saya, yang berubah itu cuma pas kita menghitung nilai TBS saja. Kalau dulu, kita tidak pernah mencatat nilai aset biologis TBS yang masih di pohon, tapi sekarang karena ada PSAK 69 jadi TBS- nya harus dihitung pake nilai wajar" (Responden, 2019).

"untuk nilai tanaman sawit tetap pakai PSAK 16" (Responden, 2019).

Pengukuran nilai aset biologis TBS pada PT $X$ dihitung menggunakan nilai wajar dikurangi biaya pada titik panen. Responden menjelaskan bahwa sampai saat ini belum ada pedoman yang mengatur secara rinci terkait bagaimana menilai suatu aset biologis. Akibatnya, setiap perusahaan dapat memiliki pertimbangan asumsi yang berbeda-beda dalam menilai aset biologisnya. Asumsi harga TBS yang digunakan oleh PT $X$ didasarkan pada harga acuan yang ditetapkan oleh Dinas Perkebunan Provinsi Kalimantan Timur. Untuk estimasi kuantitas TBS yang masih di pohon pada saat pelaporan, PT $X$ menggunakan basis realisasi panen setelah tanggal pelaporan.

"Kalau untuk harga pasar TBS, kita pakai harga acuan Disbun (Responden, 2019). 
"Kalau di sini (PT X), kita pakai estimasi dalam sebulan semua lahan akan dipanen, berarti (diasumsikan) panen Januari adalah hasil produksi Desember. Jadi, di Desember sudah ada buahnya (Responden, 2019).

"standarnya tidak mengatur, itu cara kita saja mengestimasi berapa biological asset yang ada di pohon (Responden, 2019).

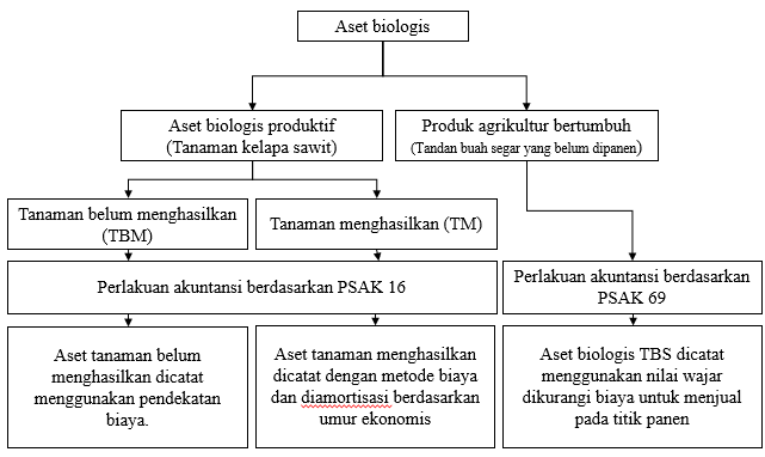

GAMBAR 4.1 PERLAKUAN AKUNTANSI ASET BIOLOGIS PADA PT $X$

Sumber: Hasil olahan penulis berdasarkan hasil analisis dokumentasi dan wawancara

Berdasarkan Gambar 4.1, penulis menyimpulkan bahwa secara garis besar perlakuan akuntansi atas aset biologis pada PT X telah sesuai dengan PSAK 69. Dari Gambar 4.1 tersebut, terlihat bahwa aset biologis pada PT $X$ dibagi menjadi dua kelompok besar yaitu aset biologis produktif dan produk agrikultur bertumbuh.

Pada PT $X$, perlakuan akuntansi terkait tanaman produktif didasarkan pada PSAK 16 karena termasuk dalam kriteria tanaman produktif (bearer plants). Menurut penulis, hal ini telah sesuai dengan PSAK 69 paragraf 01 dan 02 yang mengatur bahwa tanaman produktif yang terkait dengan aktivitas agrikultur tidak termasuk dalam ruang lingkup PSAK 69. Tanaman produktif belum menghasilkan dicatat menggunakan pendekatan biaya perolehan.

Aset tanaman belum menghasilkan dicatat menggunakan pendekatan biaya. Biaya yang dikapitalisasi terkait tanaman belum menghasilkan seperti biaya pembukaan lahan, penanaman, pemeliharaan, dan biaya lainnya yang terkait pengembangan tanaman sawit sampai tanaman tersebut siap digunakan sesuai dengan intensi manajemen yaitu pada saat tanaman telah menunjukkan tanda-tanda menghasilkan buah.

Aset tanaman menghasilkan dicatat menggunakan metode biaya. Harga perolehan tanaman menghasilkan yang dicatat merupakan akumulasi biaya yang telah diakui selama periode TBM. Aset TM diamortisasi berdasarkan estimasi umur ekonomis tanaman selama 20 tahun menggunakan metode garis lurus.

Produk agrikultur TBS dicatat berdasarkan PSAK 69 dengan menggunakan pendekatan pendapatan. Pada PT X, TBS diukur dengan cara menghitung nilai wajar dikurangi biaya panen seperti terlihat pada Tabel 4.5. Nilai wajar TBS dihitung berdasarkan hasil perkalian antara asumsi harga pasar TBS dan estimasi kuantitas TBS yang akan dipanen. Pada PT X, harga acuan TBS yang digunakan adalah harga yang ditetapkan oleh Disbun Provinsi. Untuk estimasi kuantitas TBS yang akan dipanen, PT $X$ menggunakan asumsi berdasarkan realisasi panen selama satu bulan ke depan.

\section{KESIMPULAN}

Berdasarkan hasil temuan dan diskusi, peneliti menyimpulkan bahwa secara umum, perlakuan akuntansi atas aset biologis di PT $X$ telah sesuai dengan PSAK 69. Perbedaan utama perlakuan akuntansi aset biologis pada perusahaan sawit setelah penerapan PSAK 69 adalah dengan adanya pengakuan atas produk agrikultur berupa tandan buah segar. Peneliti juga menemukan bahwa penerapan PSAK 69 ini akan menyebabkan volatilitas yang lebih besar dalam laporan laba rugi perusahaan karena adanya pencatatan terkait keuntungan dan kerugian akibat perubahan aset biologis. Selain itu, penerapan perlakuan nilai wajar atas aset biologis akan memungkinkan terjadinya perbedaan dalam teknik penilaian karena sampai saat ini belum ada pedoman yang mengatur secara rinci terkait penilaian aset biologis.

\section{REKOMENDASI}

Penelitian ini memiliki keterbatasan di mana hanya meneliti fenomena yang perlakuan akuntansi agrikultur yang terjadi pada lingkup perusahaan sawit saja. Selain itu, unit analisis yang diteliti hanya terbatas pada fenomena yang terjadi pada PT $X$ saja. Untuk penelitian 
selanjutnya, peneliti merekomendasikan agar ruang lingkup penelitian diperluas tidak hanya untuk perusahaan sawit namun juga bisa dilakukan untuk perusahaan agrikultur lain atau pada perusahaan sawit lainnya.

\section{DAFTAR PUSTAKA}

AALI (2019). Laporan Keuangan PT Astra Agro Lestari Tbk tahun 2018

Baroroh, N., Yanto, H., Fajarrini, I., \& Agustina, L. (2018). Accounting of Biological Assets in Indonesian Plantation Companies. Paper presented at the International Conference on Economics, Business and Economic Education 2018.

Benston, G. J. (2008). The shortcomings of fairvalue accounting described in SFAS 157. Journal of Accounting and Public Policy, 27(2), 101-114.

BPS. (2019). Distribusi PDB Triwulanan Atas Dasar Harga Berlaku Menurut Lapangan Usaha (Persen). Retrieved from: https://www.bps.go.id/dynamictable/201 5/05/06/828/-seri-2010-distribusi-pdbtriwulanan-atas-dasar-harga-berlakumenurut-lapangan-usaha-persen-20142018.html

Creswell, J. W. (1994). Research design: qualitative \& quantitative approaches: Sage Publications.

Elad, C., \& Herbohn, K. (2019). Implementing Fair Value Accounting in the Agricultural Sector: The UK, Australia and France.

Farida, I. (2013). Analisis Perlakuan Akuntansi Aset Biologis Berdasarkan International Accounting Standard 41 Pada PT Perkebunan Nusantara VII (Persero). Jurnal Akuntansi UNESA 2(1), 1-24. Universitas Negeri Surabaya.

Herbohn, K., \& Herbohn, J. J. S.-S. F. E., Management Policy. (2006). International accounting standard (IAS) 41: What are the implications for reporting forest assets? , 5(2), 175-189. doi:10.1007/s11842-0060009-1

IAI. (2016). Pernyataan Standar Akuntansi Keuangan 69 Agrikultur. In. Jakarta.
Lefter, V., \& Roman, A. G. (2007). IAS 41 Agriculture: Fair Value Accounting. Theoretical and Applied Economics.

Martani, D., Husnah, N., Dahliasari, D., Hidayat, T., Annisa, A., Paramita, N., \& Sumarandak, M. F. (2017). Implications of Implementation of IAS 41 about Agriculture on Foresty Accounting in Indonesia. Jurnal Keuangan Dan Perbankan, 15.

Maruli, S., \& Mita, A. F. (2010). Analisis pendekatan nilai wajar dan nilai historis dalam penilaian aset biologis pada perusahaan agrikultur: Tinjauan kritis rencana adopsi IAS 41. Simposium Nasional Akuntansi XIII Purwokerto, 1-38.

SSMS (2019). Laporan Keuangan PT Sawit Sumbermas Sarana Tbk tahun 2018

World Bank, W. D. I. (2019a). Agriculture, forestry, and fishing, value added (\% of GDP World). Retrieved from: https://data.worldbank.org/indicator/NV. AGR.TOTL.ZS

World Bank, W. D. I. (2019b). Agriculture, forestry, and fishing, value added (\% of GDP). Retrieved from: https://data.worldbank.org/indicator/NV. AGR.TOTL.ZS?locations=ID

Yin, R. K. (2009). Case Study Research: Design and Methods: SAGE Publications. 